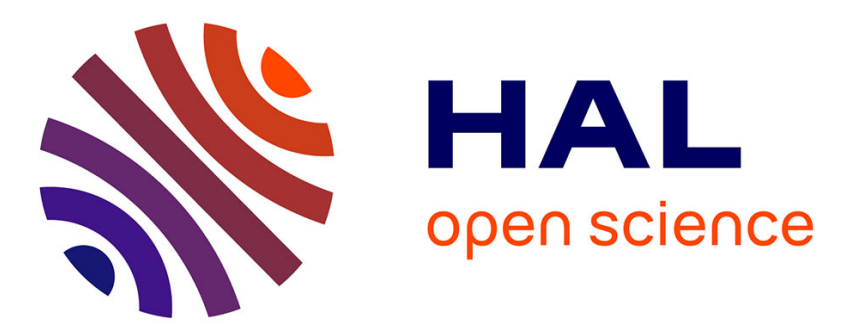

\title{
Female mound-building mice prefer males that invest more in building behavior, even when this behavior is not observed
}

Arnaud Tognetti, Guila Ganem, Michel Raymond, Charlotte Faurie

\section{To cite this version:}

Arnaud Tognetti, Guila Ganem, Michel Raymond, Charlotte Faurie. Female mound-building mice prefer males that invest more in building behavior, even when this behavior is not observed. Behavioral Ecology and Sociobiology, 2018, 72 (9), 10.1007/s00265-018-2569-4 . hal-01865013

\section{HAL Id: hal-01865013 \\ https://hal.science/hal-01865013}

Submitted on 30 Aug 2018

HAL is a multi-disciplinary open access archive for the deposit and dissemination of scientific research documents, whether they are published or not. The documents may come from teaching and research institutions in France or abroad, or from public or private research centers.
L'archive ouverte pluridisciplinaire HAL, est destinée au dépôt et à la diffusion de documents scientifiques de niveau recherche, publiés ou non, émanant des établissements d'enseignement et de recherche français ou étrangers, des laboratoires publics ou privés. 
Female mound-building mice prefer males that invest more in building behavior, even when this behavior is not observed

Arnaud Tognetti ${ }^{\mathrm{a}, \mathrm{b}^{*}}$, Guila Ganem $^{\mathrm{b}}$, Michel Raymond ${ }^{\mathrm{b}}$ \& Charlotte Faurie ${ }^{\mathrm{b}}$

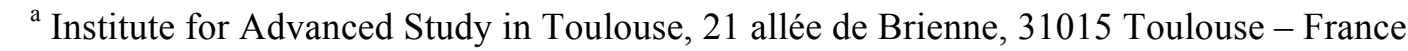

${ }^{\mathrm{b}}$ Institute of Evolutionary Sciences (ISEM), University of Montpellier, CNRS, IRD, EPHE, Montpellier - France

*Corresponding author: arnaud.tognetti@gmail.com

\section{$\underline{\text { Abstract }}$}

Through behavioral correlations, mate choice could influence the evolution of traits that are not directly selected for, or even observed. We addressed whether mound building, a unique collective behavior observed in Mus spicilegus, could be favored by female mate choice, irrespective of whether females were able to observe the behavior. First, we introduced mixed sex groups of wild-born mice in large terraria with building materials, and assessed male variation in building investment. Second, we presented females with a choice between males that invested the most versus the least in building. Females were either able to observe the males during building or not. Third, because overwintering juveniles rely on mound protection, we hypothesized that building could be a form of paternal care, and assessed whether males that invested more in building also invested more in direct offspring care. We showed that females were more attracted to males that invested the most in building, even when these behaviors were not observed. In addition, direct offspring care was negatively correlated with males' investment in building, suggesting that two alternative paternal care strategies (mound building versus direct offspring care) may exist. Our study supports the hypothesis that building could be detectable by phenotypic cues that differ from building behavior per se and that mate choice may influence the evolution and maintenance of mound building that several authors describe as a common good.

Keywords: cues, parental investment, preference, personality, sexual selection, cooperation 
In the mound-building mouse, individuals gather to build a common mound within which juveniles will spend the winter months. As some males invest more in building than others, we questioned whether females would prefer males that invest more in building behaviors, even though females could not observe males' building behaviors before mate choice. We assessed male investment in building and conducted choice tests. Females were more attracted to males that invested more in building, even when building was not observed. Hence, building investment seems detectable by phenotypic cues that differ from building behavior per se. Further, the males' investment in building was negatively correlated with their direct offspring care assessed during retrieval trials. Our findings indicate that two alternative paternal care strategies may exist in this species, and that mate choice might influence the evolution of their remarkable collective building.

\section{Acknowledgments}

We are very grateful to D. Simeonovska-Nikolova, B. Nikolovi and C. Albinet for their help for the trapping session in Bulgaria. We also thank Z. Groó, Y. Latour, A. Orth, and M. Perriat-Sanguinet, J. Barthes, J. Bovet, M. Derex, L. Danilo, V. Durand, L. Etienne, A. Nitsch, and A. Ravel, to help provided throughout the experiment and A.J. Carter who proofread the manuscript. We also thank the reviewers for their helpful comments. We thank the Ministry of Environment and Water of Bulgaria, which permitted us to catch specimen of Mus spicilegus. Supports through the ANR - Labex IAST, the CNRS of France (www.cnrs.fr), the Région Languedoc-Roussillon 'Chercheur(se)s d'Avenir' (no.: DGA3/DESR/2012/Q159) and the Fondation des Treilles (www.les-treilles.com) are gratefully acknowledged. This is contribution ISEM 2018-162. 
Introduction

Behavioral traits often form a suite of correlated traits, so-called behavioral syndromes (Sih et al. 2004a, b; Réale et al. 2010). For example, aggressiveness is associated positively with exploratory behavior and boldness in a number of species (Sih et al. 2004a, b; Groothuis and Carere 2005; Boon et al. 2008; Réale et al. 2009), and negatively associated with parental care (Mutzel et al. 2013). These behavioral correlations could result from natural and sexual selection that favor particular trait combinations (Sih et al. 2004a; Réale et al. 2010; Schuett et al. 2010, 2011; Pruitt et al. 2011; Kortet et al. 2012). Because of such associations, mate choice could indirectly select for a behavioral trait that is not a mate choice criterion, or even for signals or cues of behaviors that mates did not observe. For example, by preferring exploratory males, zebra finch females (Taeniopygia guttata) simultaneously select for more aggressive males due to an association between these traits (Schuett et al. 2011). Here we address whether individuals' investment in a common good could be indirectly selected for by an association of such behaviors with other sexually selected traits or cues. Such an association would indicate a potential role of mate preference, and possibly sexual selection, in the evolution of collective behavior and cooperation (Putland 2001; Tognetti et al. 2012; Van Vugt and Iredale 2013; Arnocky et al. 2017).

Our study model, Mus spicilegus, is a socially monogamous mouse, endemic to southeastern Europe, which possesses a mound-building behavior that is unique among mice (Tong and Hoekstra 2012). After a period of reproduction from spring to late summer, during which each adult breeding pair produces 4 to 5 litters in individual burrows of simple design (Sokolov et al. 1998), several individuals gather in late summer to collectively build a common structure in which juveniles born in late summer and early autumn will overwinter in a nest chamber located under the mound (Muntyanu 1990; Garza et al. 1997; Poteaux et al. 2008; Canady et al. 2009; Tong 2012). Several studies indicate that juveniles in a given mound may originate from several breeding pairs (up to 4) where the females are genetically related but the males are unrelated (Garza et al. 1997; Poteaux et al. 2008). In early 
(Muntyanu 1990; Sokolov et al. 1998; Simeonovska-Nikolova and Gerasimov 2000; Poteaux et al. 2008). In the northern part of the species' range, construction of mounds takes $14-21$ days and occurs from mid-August to mid-November (Muntyanu 1990; Sokolov et al. 1998; Canady et al. 2009). The mounds are built by the accumulation of plant materials covered with earth and are up to four meters in diameter and typically 0.5 meters high when freshly built (Muntyanu 1990; Sokolov et al. 1998), which supports the view that they are built collectively (a single mouse cannot build such a large structure alone (Szenczi 2012)).

The precise age structure of mound builders has yet to be established in natural conditions (Hölzl et al. 2009; Tong 2012; Tong and Hoekstra 2012). Indeed, direct observations of mound building in nature are scarce. Furthermore, trapping success can be relatively low during mound building. For example, observations done during the mound-building period in semi-natural conditions suggest that, even when they were known to be present, the adults were particularly difficult to trap (Orsini 1982). Moreover, indirect evidence through trapping around the mounds revealed that adults could represent $40 \%$ to $60 \%$ of the population of mice captured from late August to late October (Simeonovska-Nikolova 2007; Canady et al. 2009; Simeonovska-Nikolova 2012; Tong 2012) indicating that, although often not detected, adults could be present during the mound construction and that juveniles could also contribute to building (Sokolov et al. 1998; Canady et al. 2009). From November, although some adults are still found around the mounds (Canady et al. 2009; Tong 2012), the population of juveniles increases substantially (Garza et al. 1997; Milishnikov et al. 1998; Canady et al. 2009; Tong 2012), which could reflect further gathering of mice and/or events of reproduction during the building season.

Altogether, based on the available literature, it seems that the age structure of mound builders may vary, and that one or several breeding pairs and their juveniles of 3-4 weeks old, or only the juveniles, may contribute to build the mound. Hence, selection may drive mound building behavior directly and/or indirectly by increasing survival of juveniles. Here we address whether males that invest more in mound building are preferred by females. 

mound building in captivity varies between individuals (Simeonovska-Nikolova and Mehmed 2009; Serra et al. 2012; Hurtado et al. 2013). Moreover, mound size is highly variable in natural conditions (Hölzl et al. 2009) and is positively correlated with insulation against water and temperature fluctuations (Hölzl et al. 2011; Szenczi et al. 2011, 2012). Since small energy savings influence animal survival even in temperate climate (Vogt and Lynch 1982; Geiser 2004), mound size is thus expected to influence the probability of offspring survival during the European continental winter (Hölzl et al. 2011; Szenczi et al. 2011, 2012). Hence, it is likely that females would benefit from choosing hardworking builders as such partners would invest more in mound building and/or transmit their building ability to their offspring and therefore improve the probability of offspring survival during winter.

However, female mate choice takes place before mound building (for adult builders) or after the wintering period (for juvenile builders) and, thus, before the potential display of male building behavior (Muntyanu 1990; Sokolov et al. 1998). Hence, the ability of females to detect male building behavior through other signals/cues should be positively selected for. Alternatively, females could indirectly select for male building behavior through their preferences for other traits associated with males' investment in building. Furthermore, investment in mound building might be seen as a form of parental care. Behavioral experiments in Mus spicilegus revealed that males invest in offspring investment are uncoupled.

We designed our experiment to test whether females preferred males that varied in their contribution in mound building when this behavior was observed versus unobserved, and whether 
male investment in mound building was positively associated with direct paternal care. We assessed male spontaneous building behavior exhibited during mound construction in captivity by wild mice captured in agricultural fields in Bulgaria while juveniles. Then, we used two-way choice tests to assess females' attraction to males that invest more in mound building versus males that invest less. Finally, we evaluated post-mating paternal care exhibited by males with different investment in building behavior using pup retrieval experiments: we recorded the number of pups each male retrieved back to the nest after they were removed from it, and the latency to engage in the retrieving behavior. We predicted that females would be more attracted to males that invest more versus less in mound building even when the former did not observe them build. We also predicted that males that invest more in building would invest more in direct paternal care.

\section{METHODS}

\section{Capture of wild mice}

Mound-building mice were captured in northern Bulgaria in September 2011 and were then kept in the animal facilities of the University of Montpellier in France. We caught the mice in an agricultural area, at least $2 \mathrm{~km}$ away from the village of Rakita (GPS coordinates: $43^{\circ} 16^{\prime} 13.171^{\prime \prime} \mathrm{N} 24^{\circ} 16^{\prime} 16.447^{\prime \prime} \mathrm{E}$ ), using Sherman live-traps. At this time of year, the mice had already built their mounds. Live-traps were set around each mound. We weighed and measured all the mice from the nose to the base of their tail upon capture. A total of 30 males and 28 females, all subadults, captured from 14 mounds were used in this study. Same-mound mice, irrespective of their sex, were kept in the same laboratory cages from their capture until the start of the experiments two months later.

\section{Male investment in mound building}

We measured the contribution of each male to mound and nest building in large terraria two months after capture. This experiment lasted 8 weeks. Earlier studies have shown that even laboratory- 
born mice of this species would engage in mound building when building material is made available, suggesting that mound building is a spontaneous behavior (Orsini 1982; Hurtado et al. 2013). Ten groups of three males and two females were constituted. Sex composition was based on the sex-ratio observed in the wild during the mound building period (Simeonovska-Nikolova and Gerasimov 2000; Simeonovska-Nikolova and Mehmed 2009). We placed each group in a large terrarium ( 1 x 1 x $0.8 \mathrm{~m})$ containing approximately $0.2 \mathrm{~m}^{3}$ of earth and stones. The room was maintained at $21 / 23^{\circ} \mathrm{C}$ under a 12:12 light/dark cycle (corresponding roughly to the photoperiod observed in the field in September/October) with lights on at $9.00 \mathrm{pm}$. Water was available ad libitum, and food was provided on a weekly basis, although daily visits were made to check the well-being of the mice. At the beginning of each observation session, straw and seeds were provided as building materials in addition to the earth and stones already present in the terrariums. Both males and females participated in building. However, we only recorded male behaviors. For each male, five categories of behavior were recorded: the number of times it dug, carried straw, carried seeds, carried stones, and entered the nest (Fig. S1). The latter was recorded because the mice were observed entering the nest to build it and shape it from inside. A single investigator (AT) observed each group during 5 sessions of 1 hour each, approx. one week apart. Males were ear tagged $(7.8$ × $2.8 \mathrm{~mm}$, Fine Science Tools $\mathrm{GmbH})$ for identification. For each terrarium, the number of metallic earrings ( 1 or 2 ) and the side of the tag (right ear, left ear, or both) allowed individual mice to be recognized without having to handle them.

We could constitute only five groups of same-mound individuals (three males and two females). The other five groups included three same-mound males to limit aggression (Sokolov et al. 1998) and two same-mound females from a mound different to that of the males. Unfortunately, for four out of these five groups, we observed high female mortality $(n=8)$ during the first night in the enclosure, most likely due to males' aggressiveness. Following this observation, we immediately removed the two remaining females from the fifth terrarium and placed them in a separate cage.

We averaged the data collected during the five observation sessions for each male and for each of the five behavioral items recorded during building (transport of straw, seeds, and stone, digging and entering the nest). As highlighted in Fig. S1, mice build a nest as well as a structure closely resembling 
a mound that had all the characteristics described in the field: i.e. seed storage covered with earth and plants materials. However, although seed transport and storage did take place (Fig. S1), because 22 out of 30 mice were not observed transporting seeds, we removed this variable from the analysis. A principal component analysis (PCA) was applied to the four remaining behavioral items with the aim of extracting a single factor reflecting male building investment (function prcomp in $\mathrm{R}$ ).

and males of a given group were kept in separate cages to prevent reproduction. They were maintained in laboratory conditions under a 13.5:10.5 h light/dark cycle (light at $6.30 \mathrm{pm}$ ), corresponding to the photoperiod during the breeding season (early spring). Food and water were available ad libitum, and cotton was provided as nesting material. They were kept in these conditions until the beginning of the next experiment.

\section{Female attraction}

We measured female attraction to males in a Y maze following the procedure described in Smadja and Ganem (2002) six months after their capture. The stimuli were composed of 5 pairs of males. Males of each pair shared the same terrarium during the mound-building experiment and belonged to one of the five terraria in which females were present. In each of these terraria, we selected among the three males the male that invested the most and the male that invested the least in order to present to the females a choice between contrasting levels of building behavior. To that aim, we used the PCA factor reflecting the most male investment in building (see Results).

Each female was tested once. We tested female attraction to males that invested the most versus the least in building when building was observed (females that shared an enclosure with 3 males during mound building were presented with a choice between the male that invested in building the most or the least in the triad) ( $\mathrm{n}=10$ females), and when building was unobserved (females that did not share an enclosure with males were given the choice between a pair of males composed of the males that invested the most and the least from a triad randomly chosen) ( $\mathrm{n}=10$ females). 
A single investigator (AT) conducted all the tests. All mice were more than 6 months old and

sexually mature. To maximize the expression of sexual attraction, females were tested while sexually receptive (i.e., estrus or proestrus/estrus, assessed with vaginal smears).

The Y maze was transparent (plexiglas and plastic ware) and composed of a main branch (5 $\mathrm{cm}$ diameter, $35 \mathrm{~cm}$ long) connected to two secondary branches (5 $\mathrm{cm}$ diameter, $25 \mathrm{~cm}$ long). Boxes $(35 \times 23 \times 13 \mathrm{~cm})$ with transparent perforated doors were connected at the end of each branch (for an illustration of the apparatus see: Smadja and Ganem 2002). One week before the experiment, each female was allowed to explore the empty Y maze for 15 minutes in order to become habituated.

At the start of each test, a female was placed in a box connected to the main branch of the apparatus. The two stimuli were randomly assigned to one or the other peripheral boxes (the identities of the stimuli was not known by the observer). We then opened the door of the female's box and started to record its behavior when the female crossed the box door. In all tests, the females entered both secondary branches of the Y maze. During the 10-minute observation, we recorded the time spent by females: i) in each secondary branch (including when females were in contact with the perforated door but when the male was not behind the door), and ii) interacting with the male, or sniffing or licking the transparent perforated door when the male was just behind the door. This is a classical method to measure female preference (e.g. Smadja and Ganem 2005; Latour et al. 2013) that was shown to constitute a good proxy of female propensity to engage in mating with the preferred male (Patris and Baudoin 1998; Smadja and Ganem 2002). We implemented General Linear Mixed Models to test whether male attraction was influenced by their investment in building. For this purpose, we used GLMMs with a quasi-binomial error structure ( $g \operatorname{lmm} P Q L$ function of the MASS package in R) in which we included the identity of each pair of males as a random effect. In the first model, the response variable was the proportion of time spent by the female in the left versus right side of the maze. In a second model, it was the proportion of time the female was in close contact with the male of the left versus right side of the maze. In both models, we included two explanatory variables: (i) a binary variable concerning male investment in building ( 1 if the male on the left was the one that invested the most in building behaviors, 0 if it was the male that invested the least) and (ii) a binary 
variable reflecting the treatment ( 1 if the female observed male building behaviors, 0 if not). We also tested the interaction between these two variables to test whether observing male building influenced female preferences. When the interaction was not significant, we removed it from the model.

At the end of the experiment, all individuals were returned to their home cage and maintained under laboratory conditions until the next experiment.

\section{Direct paternal care}

We used a pup retrieval procedure, a test used commonly to measure parental care in rodents (Dudley 1974; Cohen-Salmon et al. 1985), including Mus spicilegus (Patris and Baudoin 2000). We first randomly paired females $(\mathrm{n}=20)$ and 'unfamiliar' males (i.e., captured in different mounds in the field). During the first week, the two members of the pair were maintained in the same cage but separated with a wire net so that they could first become familiar with each other. We maintained them in laboratory conditions under a 13.5:10.5 light/dark cycle (light at $6.30 \mathrm{pm}$ ), corresponding to the photoperiod of the breeding season in the field. Food and water were available ad libitum, and cotton was provided as nesting material. Ten of the 20 pairs successfully bred (a low breeding rate is often observed for wild-born mice kept under laboratory conditions, GG pers. obs.) and could hence participate in this experiment that began 18 months after capture. Litter size varied from 5 to 12 pups.

On the day of birth, we placed the mice in a large terrarium $(70 \times 30 \times 30 \mathrm{~cm})$. The terrarium contained clean sawdust, food and water. One corner also contained cotton and cardboard rolls as nestbuilding material.

All males were tested twice: approximately four days (mean \pm SD: $3.7 \pm 0.8$ days) and six days $(6.3 \pm 0.9$ days $)$ after the birth of their first litter. During these two sessions, we first removed the breeding pair from the terrarium. We then removed three of the pups from the nest and placed them at the opposite end of the terrarium. We isolated these three pups from their littermates and the nest by placing a transparent plastic separation in the middle of the terrarium. The male was then put back in 
the side of the terrarium containing the nest. After 30 seconds, we removed the plastic separation and we measured (i) male latency before the start of retrieval of the isolated pups, and (ii) the number of pups retrieved to the nest during the next fifteen minutes. Both of these measures were averaged over the two test sessions, and we used Spearman correlation tests (two-tailed tests, function cor.test in R) to assess their potential association with the male building score measured during the mound-building experiment (first experiment above). For males that did not retrieve any pups, the male latency to retrieve was set at 15 minutes (i.e., the duration of the experiment). Because the Spearman correlation test relies on ranks, this choice did not influence the results.

Because this species is nocturnal and particularly active during the first few dark hours (Simeonovska-Nikolova and Mehmed 2009), all observations (mound building, female preferences, and paternal investment) were conducted one to two hours after the beginning of the dark period under dim red light. To minimize observer bias, we used blind methods when behavioral data were recorded (preferences tests and retrieval experiments). We recorded all observations using the Observer software Version 5 (Noldus Information Technology). All statistical analyses were performed using the R software, version 3.4.2 (R Core Team 2017).

\section{RESULTS}

\section{Male investment in building}

In total, during the 50 hours of observation, each male transported 0 to 70 pieces of straw (mean $\pm \mathrm{SD}$ : $18.1 \pm 19.4)$, and 1 to $99(20.9 \pm 23.9)$ stones (approximately $1 \mathrm{~cm}^{3}$ in size). The frequency of digging varied between 0 and 35 times $(10.1 \pm 8.9)$, and they entered their nest 2 to 35 times $(12.6 \pm 9.9)$. We used a PCA to extract a single factor reflecting male global investment in mound building and avoiding giving too much weight to a specific behavior. The first two axes of the PCA, including the four building items, captured $80 \%$ ( $45 \%$ and $34 \%$ respectively) of the total variation. The first axis was positively correlated with the number of times a male entered the nest $(r=0.42)$, negatively correlated with stones transport $(\mathrm{r}=-0.66)$ and digging frequency $(\mathrm{r}=-0.62)$, and not correlated with 
straw transport $(\mathrm{r}=0.06)$. We hence considered that this axis could represent a measure of specialization in building tasks (Serra et al. 2012; Hurtado et al. 2013) rather than a measure of global investment. The second axis was positively correlated with all four variables: frequency of digging ( $\mathrm{r}$ $=0.28)$, number of stones $(\mathrm{r}=0.17)$ and straw transported $(\mathrm{r}=0.76)$, and number of entrances into the nest $(\mathrm{r}=0.57)$, and we considered that it could reflect male global investment in building and hence a pertinent measure allowing to identify males that invested the most and the least in building behaviors.

Investment in building was not related to male weight $(10.26 \pm 0.87$ grams $)$ or size $(7.14 \pm 0.34$ $\mathrm{cm}$ ) at capture (Spearman correlation test: weight: $\rho=0.11, p=0.58$, size: $\rho=0.01, p=0.95$ ) nor to their weight $(11.64 \pm 1.6$ grams $)$ at the end of the building experiment $(\rho=0.13, p=0.53)$. Moreover, we did not detect any difference in individual building when comparing males belonging to mixed groups (containing females) to males belonging to all-male groups (Wilcoxon rank sum test: $\mathrm{W}=86$, $p=0.43)$

\section{Female attraction}

We found no effect of the interaction between male investment in building and treatment in any model, suggesting that observing male building behaviors did not influence female attraction (glmmPQL with time spent by females $(\mathrm{n}=20)$ in the branches as response variable: $\mathrm{t}=1.00, P=0.92$; glmmPQL with time spent by females $(\mathrm{n}=15)$ in close proximity to the males as response variable: $\mathrm{t}=-$ $1.03, P=0.34)$.

Male investment in building did not influence the proportion of time females $(n=20)$ spent exploring the two branches $(52 \%$ of time was spent on the side of the male that invested the most versus the least; glmmPQL: $\mathrm{t}=1.30, P=0.21$; Table S1; Fig. 1). However, it did significantly influence the proportion of time females $(n=15)$ spent in proximity to the males $(75 \%$ of time was spent close to the male that invested the most versus the least; glmmPQL: $\mathrm{t}=3.69, P=0.006$; Table S2; Fig. 1): females spent more time in close proximity to the male that invested the most in building behaviors compared to the time spent with the male that invested the least (median $\left[1^{\text {st }}\right.$ quartile; $3^{\text {rd }}$ quartile $]$ of 
the difference of time spent with the male that invested the most versus the least in building behaviors $=8.4[4.6 ; 11.7] \mathrm{s})$.

\section{Investment in mound building \& direct paternal care}

The males $(n=10)$ retrieved 0 to 3 pups at each session (median $\left[1^{\text {st }}\right.$ quartile; $3^{\text {rd }}$ quartile]: $1.5[0 ; 3]$ for the first session; $2.5[0.25 ; 3]$ for the second session). For each male, the number of pups retrieved during the first versus the second session was not significantly different (paired Wilcoxon rank test: 0 $[-0.75 ; 0]$ pups, $\mathrm{V}=5.5, p=0.68)$. For sessions in which at least one pup was retrieved $(\mathrm{n}=12)$, the latency to retrieve the first pup was between 23 and 810 seconds $(171[36 ; 325] \mathrm{s})$.

Direct paternal care was negatively associated with male investment in building: across the 20 sessions, the males that invested more in building retrieved fewer pups back to the nest (Spearman correlation test: $\mathrm{n}=10$ males, $\rho=-0.67, p=0.04$; Fig. $2 \mathrm{a}$ ) and presented a higher latency to retrieve the first pup ( $\mathrm{n}=10$ males, $\rho=0.71, p=0.02$; Fig. $2 \mathrm{~b}$ ).

\section{Discussion:}

Mate choice and sexual selection could favor the evolution of traits that are not directly selected for (Schuett et al. 2010, 2011). Here we addressed whether mound building, a spontaneous behavior observed both in wild- and laboratory-born individuals of Mus spicilegus, could be favored during female mate choice even though females were not able to observe the building activity of males. Indeed, the presence of adults and juveniles around mounds during the building period suggests that the two cohorts (adults and juveniles when 3-4 weeks old) could be involved in building (Simeonovska-Nikolova 2007, 2012; Canady et al. 2009; Tong 2012), further indicating that mate choice would take place before mound building (for the adults) or after (for the juveniles) and involve unfamiliar partners (Garza et al. 1997). Aiming to get insight into the mechanisms favoring building behavior, we asked whether female mate choice could favor males that invest more versus less in 
mound building behaviors and whether males that invest more are also more involved in direct parental care using pup-retrieval experiments.

Our findings indicate that females were more attracted to males that invested more in building behaviors over males that invested less, even when building behaviors were not observed. This suggests that female attraction to males could be influenced by cues that are different from building behaviors per se, or by attraction to traits associated with male investment in building. We also show that direct parental care is negatively correlated with male investment in mound building, suggesting a trade-off between these two behaviors.

Our findings raise the question of which signals or cues females are responding to when they show an attraction to males that invest more in mound building. In our experiment, females were more attracted to males that invested more versus less in building, even without having observed them build. Hence, phenotypic cues advertising male investment in building may exist in this species. Such cues could be based on acoustic, olfactory, or visual traits, since all of them are involved in mice communication (e.g.: Hurst and Beynon 2004; Musolf et al. 2010) and were available to females in our test apparatus. Their detection by females could influence their sexual preferences, as some sexual pheromones do in several species, including mice (Roberts et al. 2010; Li and Liberles 2015). An alternative explanation could also be that female attraction to males that invest more in building was not directed to building per se but to other traits with which investment in building is associated. We did not observe any link between male size or weight and investment in building, suggesting that male condition is unlikely to be one of these traits. Interestingly, experimental studies in the moundbuilding mouse found that agonistic behaviors between unfamiliar males and females are positively linked with sexual motivation (Busquet et al. 2009; Simeonovska-Nikolova and Lomlieva 2012). Because of the expected high cost of mound building and its important role in the success of overwintering, individuals that invest more in mound building are likely to more aggressively protect resources and defend their mound from intruders. We can therefore speculate that male aggressiveness or dominance might be sexually selected traits associated with building, leading to the indirect selection of building behavior through female mate choice. During our preference tests, we did not 
observe agonistic behaviors between males and females through the perforated doors; furthermore, males that invested more in mound building were not observed to try to attract more female attention than males that invested less. However, chemosensory cues of dominance and aggressiveness are present in the urine and preputial glands of male mice and therefore could have been detected by females during their interactions with the males (Harvey et al. 1989; Hurst and Beynon 2004; Soini et al. 2009; Mucignat-Caretta and Caretta 2014). Follow-up studies should thus investigate which traits are used by female Mus spicilegus during mate choice that are associated with building behavior. Such studies may particularly focus on dominance, aggressiveness and other personality traits.

In Mus spicilegus, the inclination of females to prefer males that invest more in mound building could be an adaptive strategy. Choosing a male that invests highly in building could increase females' fitness in several ways. First, since mound size is positively correlated with water-insulation and soil temperature inside the mound (Hölz et al. 2011; Szenczi et al. 2011, 2012), choosing a male that invests more energy and time in mound building could increase offspring survival during the winter. Second, mound-building behavior seems to be genetically heritable (Orsini 1982). If the level of investment in building was also heritable, by choosing a male that invests more in building, females could improve the ability of their offspring to build a mound, and hence increase the chance of survival of their own progeny. Third, given the attractiveness of the males that invest more in building behaviors, females could also increase their sons' reproductive success (sexy son hypothesis: Weatherhead and Robertson 1979).

Interestingly, we found a negative correlation between direct paternal care and building investment. Previous experimental studies involving the mound-building mouse found intense paternal investment, such as covering and warming the pups (Patris and Baudoin 2000), and males that exhibited the highest levels of offspring attendance increased their reproductive success by reducing their mate's inter-litter intervals (Feron and Gouat 2007). As both parental investment and building are likely to be energetically costly, the negative association observed between them may indicate the existence of a tradeoff. In addition, since parents are likely to build a mound for their offspring, mound building may be considered a form of parental care (as defined by (Royle et al. 2012)). In this case, 
this negative association might suggest the existence of two alternative parental care strategies. Hence, an interpretation of our results could be that different behavioral traits may correspond to different types of fathers with regard to how they take care of offspring. Such alternative strategies in offspring care were previously observed in some cooperative breeding species, such as cichlids, Neolamprologus pulcher, or the noisy miner, Manorina melanocephala, in which different types of helpers seem to exist (Arnold et al. 2005; Bergmüller and Taborsky 2007), but to our knowledge, they were not extensively studied in relation to parental care.

Cooperative behavior is defined as a behavior that benefits others while reducing the relative fitness of the performer of that behavior and hence could be selected against (West et al. 2007). Mound building possesses a priori those characteristics and we propose that it may be considered as a cooperative behavior, favored by female mate choice as observed in humans (Farrelly et al. 2007; Tognetti et al. 2014, 2016; Arnocky et al. 2017) and some cooperatively breeding birds (Reyer 1984; Jones 1998; Doutrelant and Covas 2007).

A limitation of our study concerns the small sample sizes, due to restrictions on field captures, and unexpected mortality events. Nevertheless, male investment in building significantly influenced female attraction and this result is particularly promising for more extensive research.

In conclusion, our results raise questions about the mechanisms involved in the evolution of mound building and provide support to the hypothesis that such behavior could be detectable by phenotypic cues different from building per se. While the mechanisms enabling females to prefer the males that invest the most in building behaviors in this species are still unknown, our results suggest that mate choice might influence the evolution and maintenance of mound building. Last but not least, several authors pointed out the collaborative aspect of mound building, and some evidence indicates that several breeding pairs and their offspring could be involved in building this common good. Future studies should test whether building could be considered a cooperative behavior and whether sexual selection is another pathway by which cooperative building in this species might evolve. 


\section{Compliance with Ethical Standards}

421

422

423

424

425

426

427

428

429

430

431

432

433

434

435

436

437

438

439

440

441

442

443

444

445

446

Ethical Approval

Mouse sampling was performed with the authorization of the Bulgarian Ministry of the Environment and Water (permit $\mathrm{N}^{\circ} 33-00-140$ ). The study complied with all the relevant laws of France and mice handling and behavioral tests were authorised by the French authorities (Direction Départementale de la Protection des Populations de l'Hérault - Ministère de l'Agriculture, permit $\left.\mathrm{N}^{\circ} \mathrm{C} 34-265\right)$. This study also followed the ABS/ASAB guidelines for the ethical treatment of animals. We were particularly committed to limiting the number of mice trapped and tested, and mice were provided an enriched environment and diversified food to reduce their stress as much as possible.

\section{Conflict of Interest}

The authors declare that they have no conflict of interest.

\section{Data availability}

The datasets analysed during the current study are available in the figshare repository, https://doi.org/10.6084/m9.figshare.5562664

\section{References}

Arnocky S, Piché T, Albert G, Ouellette D, Barclay P (2017) Altruism predicts mating success in humans. Brit J Psychol 108:416-435

Arnold KE, Owens IPF, Goldizen AW (2005) Division of labour within cooperatively breeding groups. Behaviour 142:1577-1590

Bartsch C, Weiss M, Kipper S (2015) Multiple song features are related to paternal effort in common nightingales. BMC Evol Biol 15:115. doi: 10.1186/s12862-015-0390-5

Bergmüller R, Taborsky M (2007) Adaptive behavioural syndromes due to strategic niche specialization. BMC Ecol 7:12

Boon AK, Réale D, Boutin S (2008) Personality, habitat use, and their consequences for survival in North American red squirrels Tamiasciurus hudsonicus. Oikos 117:1321-1328

Busquet N, Nizerolle CL, Feron C (2009) What triggers reproductive life? Effects of adolescent 
Canady A, Mosansky L, Stanko M (2009) First knowledge of winter ecology of the mound-building mouse (Mus spicilegus Petenyi, 1882) from Slovakia. Acta Zool Bulgar 61:79-86

Cohen-Salmon C, Carlier M, Roubertoux P, Jouhaneau J, Semal C, Paillette M (1985) Differences in patterns of pup care in mice $\mathrm{V}-$ Pup ultrasonic emissions and pup care behavior. Physiol Behav $35: 167-174$

Doutrelant C, Covas R (2007) Helping has signalling characteristics in a cooperatively breeding bird. Anim Behav 74:739-747

Dudley D (1974) Paternal behavior in the california mouse, Peromyscus californicus. Behav Biol $11: 247-252$

Farrelly D, Lazarus J, Roberts G (2007) Altruists attract. Evol Psychol 5:313-329

Feron C, Gouat P (2007) Paternal care in the mound-building mouse reduces inter-litter intervals.

Ferrero DM, Lemon JK, Fluegge D, Pashkovski SL, Korzan WJ (2011) Detection and avoidance of a carnivore odor by prey. P Natl Acad Sci USA 108:11235-11240

Garza JC, Dallas J, Duryadi D, Gerasimov S, Croset H, Boursot P (1997) Social structure of the mound-building mouse Mus spicilegus revealed by genetic analysis with microsatellites. Mol Ecol 6:1009-1017

Geiser F (2004) Metabolic rate and body temperature reduction during hibernation and daily torpor. Annu Rev Physiol 66:239-274. doi: 10.1146/annurev.physiol.66.032102.115105

Gleason ED, Marler CA (2010) Testosterone response to courtship predicts future paternal behavior in the California mouse, Peromyscus californicus. Horm Behav 57:147-154

Groothuis TGG, Carere C (2005) Avian personalities: characterization and epigenesis. Neurosci Biobehav Rev 29:137-150

Harvey S, Jemiolo B, Novotny M (1989) Pattern of volatile compounds in dominant and subordinate male mouse urine. J Chem Ecol 15:2061-2072

Hill GE (1991) Plumage coloration is a sexually selected indicator of male quality. Nature 350:337 Press, Cambridge, MA

Hölzl M, Hoi H, Darolova A, Kristofik J, Penn DJ (2009) Why do the mounds of Mus spicilegus vary so much in size and composition? Mamm Biol 74:308-314

Hölzl M, Hoi H, Darolova A, Kristofik J (2011) Insulation capacity of litter mounds built by Mus spicilegus: physical and thermal characteristics of building material and the role of mound size. Ethol

480 Ecol Evol 23:49-59

Hurst JL, Beynon RJ (2004) Scent wars: the chemobiology of competitive signalling in mice. 
Hurtado MJ, Fénéron R, Gouat P (2013) Specialization in building tasks in the mound-building mouse, Mus spicilegus. Anim Behav 85:1153-1160. doi: 10.1016/j.anbehav.2013.03.020

Jones DA (1998) Parentage, mate removal experiments, and sex allocation in the cooperatively breeding bell miner, Manorina melanophyrs. MSc thesis, Queen's University, Canada

Kortet R, Niemelä PT, Vainikka A, Laakso J (2012) Females prefer bold males; an analysis of boldness, mate choice, and bacterial resistance in the field cricket Gryllus integer. Ecol Parasitol Immunol 1:1-6

Latour Y, Perriat-Sanguinet M, Caminade P, Boursot P, Smadja C, Ganem G (2013) Sexual selection against natural hybrids may contribute to reinforcement in a house mouse hybrid zone. Proc R Soc B $281: 20132733$

Li Q, Liberles SD (2015) Aversion and attraction through olfaction. Curr Biol 25:R120-R129

Milishnikov AN, Rafiev AN, Muntianu AI (1998) Genotypic variability in populations of moundbuilder mice Mus spicilegus Pet., 1882, at different life-cycle stages. Genetika 34:947-952

Mucignat-Caretta C, Caretta A (2014) Message in a bottle: major urinary proteins and their multiple roles in mouse intraspecific chemical communication. Anim Behav 97:255-263

Muntyanu AI (1990) Ecological features of an overwintering population of the Hillock mouse (Mus hortulanus Nordm) in the South-West of the USSR. Biol J Linn Soc 41:73-82

Musolf K, Hoffmann F, Penn DJ (2010) Ultrasonic courtship vocalizations in wild house mice, Mus musculus musculus. Anim Behav 79:757-764. doi: 10.1016/j.anbehav.2009.12.034

Mutzel A, Dingemanse NJ, Araya-Ajoy YG, Kempenaers B (2013) Parental provisioning behaviour plays a key role in linking personality with reproductive success. Proc R Soc B 280:20131019

Orsini P (1982) Facteurs régissant la répartition des souris en Europe : intérêt du modèle souris pour une approche des processus évolutifs. PhD thesis, University of Montpellier 2

Östlund S, Ahnesjö I (1998) Female fifteen-spined sticklebacks prefer better fathers. Anim Behav 56:1177-1183. doi: 10.1006/anbe.1998.0878

Patris B, Baudoin C (1998) Female sexual preferences differ in Mus spicilegus and Mus musculus domesticus: the role of familiarization and sexual experience. Anim Behav 56:1465-1470

Patris B, Baudoin C (2000) A comparative study of parental care between two rodent species: implications for the mating system of the mound-building mouse Mus spicilegus. Behav Process $51: 35-43$

Poteaux C, Busquet N, Gouat P, Katona, K, Baudoin, C (2008) Socio-genetic structure of moundbuilding mice, Mus spicilegus, in autumn and early spring. Biol J Linn Soc 93:689-699

Préault M, Chastel O, Cézilly F, Faivre B (2005) Male bill colour and age are associated with parental abilities and breeding performance in blackbirds. Behav Ecol Sociobiol 58:497-505. doi: $10.1007 / \mathrm{s} 00265-005-0937-3$

Pruitt JN, Riechert SE, Harris DJ (2011) Reproductive consequences of male body mass and aggressiveness depend on females' behavioral types. Behav Ecol Sociobiol 65:1957-1966 
Putland D (2001) Has sexual selection been overlooked in the study of avian helping behaviour? Anim Behav 62:811-814

R Core Team (2017) R: A language and Environnement for Statistical Computing. R Foundation for Statistical Computing, Vienna, Austria, http://www.R-project.org

Réale D, Garant D, Humphries MM, Bergeron P, Careau V, Montiglio PO (2010) Personality and the emergence of the pace-of-life syndrome concept at the population level. Phil Trans R Soc B 365:4051-4063

Réale D, Martin J, Coltman DW, Poissant J, Festa-Bianchet M (2009) Male personality, life-history strategies and reproductive success in a promiscuous mammal. J Evol Biol 22:1599-1607

Reyer H-U (1984) Investment and relatedness - a cost/benefit analysis of breeding and helping in the pied kingfisher (Ceryle rudis). Anim Behav 32:1163-1178

Roberts SA, Simpson DM, Armstrong SD, Davidson AJ, Robertson DH (2010) Darcin: a male pheromone that stimulates female memory and sexual attraction to an individual male's odour. BMC Biol 8:75

Royle NJ, Smiseth PT, Kölliker M (2012) The evolution of parental care. Oxford University Press, Oxford

Schuett W, Godin J-GJ, Dall SRX (2011) Do female zebra finches, Taeniopygia guttata, choose their mates based on their 'personality'? Ethology 117:908-917

Schuett W, Tregenza T, Dall SRX (2010) Sexual selection and animal personality. Biol Rev 85:217246

Serra J, Hurtado MJ, Le Négrate A, et al (2012) Behavioral differentiation during collective building in wild mice Mus spicilegus. Behav Process 89:292-298

Sih A, Bell A, Johnson JC (2004a) Behavioral syndromes: an ecological and evolutionary overview. Trends Ecol Evol 19:372-378

Sih A, Bell AM, Johnson JC, Ziemba RE (2004b) Behavioral syndromes: an integrative overview. Q Rev Biol 79:241-277

Simeonovska-Nikolova DM (2007) Spatial organization of the mound-building mouse Mus spicilegus in the region of northern Bulgaria. Acta Zool Sinica 53:22-28

Simeonovska-Nikolova D (2012) Neighbour relationships and spacing behaviour of mound-building mouse, Mus spicilegus in summer. Acta Zool Bulgar 64:135-143

Simeonovska-Nikolova D, Gerasimov S (2000) Seasonal changes of some population characteristics of Mus spicilegus Petenyi in North Bulgaria. Acta Zool Bulgar 52:81-90

Simeonovska-Nikolova D, Lomlieva M (2012) Sociosexual behavior of female mound-building mice, Mus spicilegus, in a forced-pairing experiment. Nat Math Sci 2:1-5

Simeonovska-Nikolova D, Mehmed S (2009) Behavior of mound-building mouse, Mus spicilegus, during autumn-winter period in captivity. Biotechnol Biotechnol Equip 23:180-183 
Smadja C, Ganem G (2002) Subspecies recognition in the house mouse: a study of two populations from the border of a hybrid zone. Behav Ecol 13:312-320

Smadja C, Ganem G (2005) Asymmetrical reproductive character displacement in the house mouse. J Evol Biol 18:1485-1493

Soini HA, Wiesler D, Koyama S, Feron C, Baudoin C, Novotny MV (2009) Comparison of urinary scents of two related mouse species, Mus spicilegus and Mus domesticus. J Chem Ecol 35:580-589

Sokolov VE, Kotenkova EV, Michailenko AG (1998) Mus spicilegus. Mamm Species 592:1-6

Szenczi P, Banszegi O, Ducs A, Gedeon CI, Marko G, Nemeth I, Altbacker V (2011) Morphology and function of communal mounds of overwintering mound-building mice (Mus spicilegus). $\mathrm{J}$ Mammal 92:852-860

Szenczi P, Kopcso D, Banszegi O, Altbacker V (2012) The contribution of the vegetable material layer to the insulation capacities and water proofing of artificial Mus spicilegus mounds. Mamm Biol $77: 327-331$

Szenczi PM (2012) Social behavior, cooperation and ecological constraints on two closely related mice species. PhD thesis, Eötvös Loránd University, Budapest, Hungary

Tognetti A, Berticat C, Raymond M, Faurie C (2012) Sexual selection of human cooperative behaviour: an experimental study in rural Senegal. PLoS ONE 7:e44403

Tognetti A, Berticat C, Raymond M, Faurie C (2014) Assortative mating based on cooperativeness and generosity. J Evol Biol 27:975-981

Tognetti A, Dubois D, Faurie C, Willinger M (2016) Men increase contributions to a public good when under sexual competition. Sci Rep 6:29819

Tong W (2012) Causes and Consequences of Cooperative Construction in the Mice Mus spicilegus and Peromyscus polionotus. PhD thesis, Harvard University

Tong W, Hoekstra H (2012) Mus spicilegus. Curr Biol 22:R858-R859

Van Vugt M, Iredale W (2013) Men behaving nicely: Public goods as peacock tails. Brit J Psychol $104: 3-13$

Vogt FD, Lynch GR (1982) Influence of ambient temperature, nest availability, huddling, and daily torpor on energy expenditure in the white-footed mouse Peromyscus leucopus. Physiol Zool 55:56-63. doi: 10.1086/physzool.55.1.30158443

Weatherhead PJ, Robertson RJ (1979) Offspring quality and the polygyny threshold: "the sexy son hypothesis.” Am Nat 113:201-208. doi: 10.2307/2460199

West SA, Griffin AS, Gardner A (2007) Evolutionary explanations for cooperation. Curr Biol 17:661672 


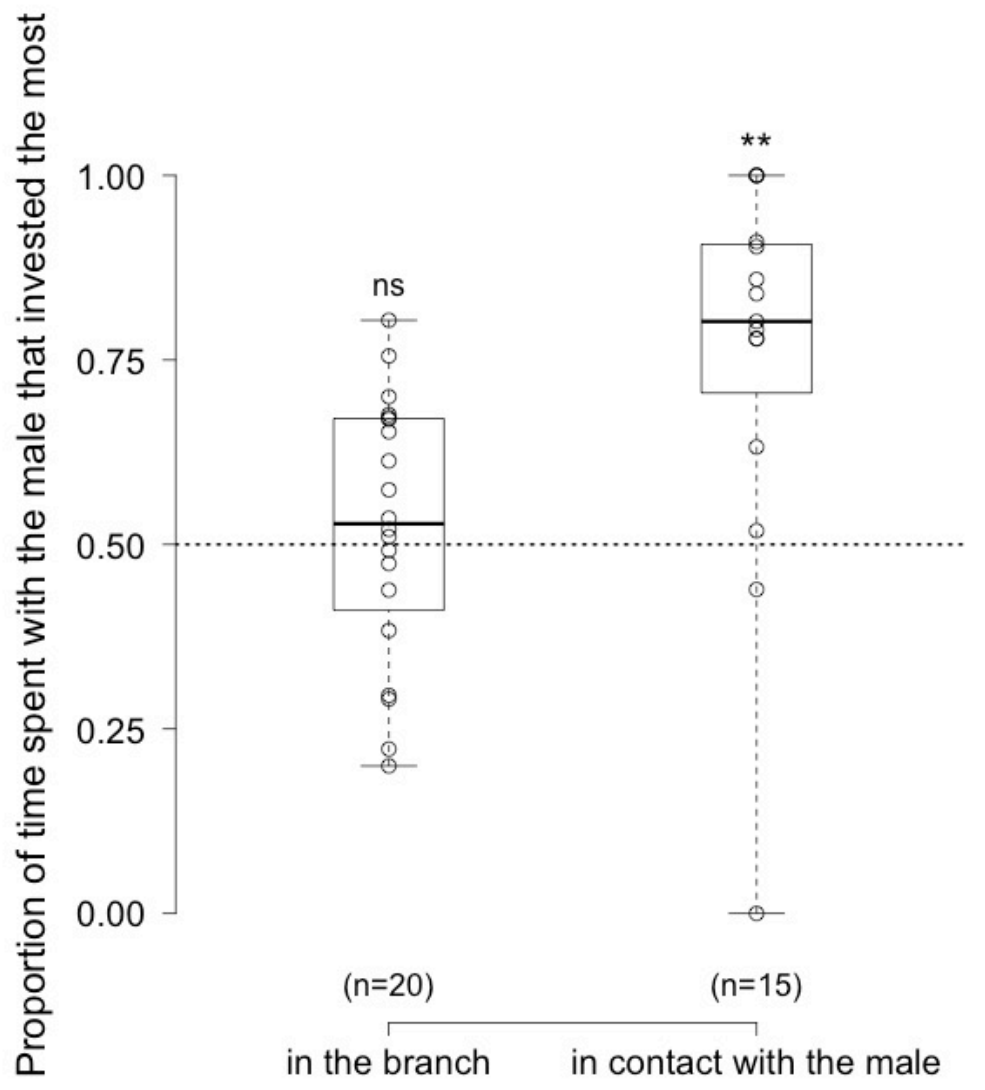

592

$593 \quad$ Fig. 1

594 Box plot representation of the proportion of time females spent exploring the branch of, or in 595 proximity to the male most involved in building, relative to the total time spent exploring the two 596 branches or in close proximity to the two males. The horizontal dotted line corresponds to a random 597 choice. A value over 0.50 indicates preference for the male that invests the most in mound building. 598 Medians (thick lines), first and third quartiles, whiskers representing the entire data range and individual data points are indicated. ns: non-significant, $* * \mathrm{p}<0.01$ 


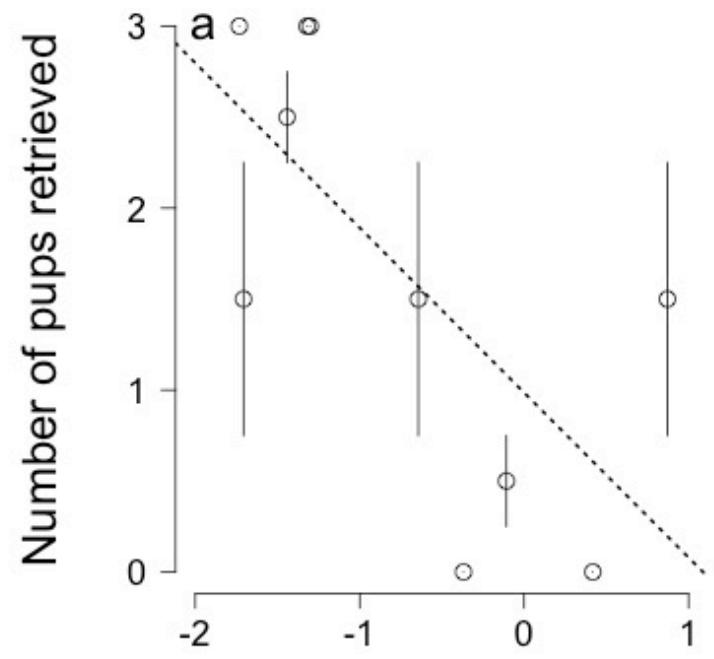

Male investment in building

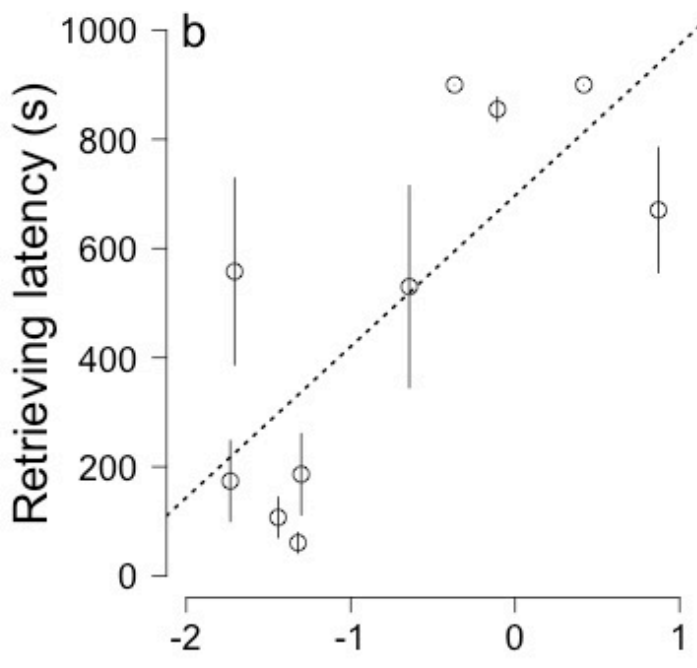

Male investment in building

601 Fig. 2

602 Relationship between male investment in building and paternal care, measured as the average number 603 of pups retrieved to the nest (a), and as the latency to retrieve the first pup to the nest (b). Error bars 604 represent the standard error of the mean. Spearman correlation tests indicate that males investing more 605 in mound building retrieved fewer pups back to the nest and presented a higher latency to retrieve the 606 first pup. 
609

Table S1. Influence of male investment in building and treatment (observed building by the female versus not) on the proportion of time females spent exploring the left versus right side of the maze $(\mathbf{n}=\mathbf{2 0})$. We used a Generalized linear mixed model fitted by penalized quasi-likelihood (glmmPQL, binomial error), with male pair's identity as a random effect. We included two explanatory variables: a binary variable concerning male investment in building ( 1 if the male on the left was the one that invested the most in building behaviors, 0 if it was the male that invested the least) and a binary variable reflecting the treatment ( 1 if the female observed male building behaviors, 0 if not). The initial model also considered the interaction between male investment in building and treatment, but it was excluded during model simplification due to its non-significance.

619

620

\begin{tabular}{lccccc}
\hline Predictor variables & Estimate & S.E. & df & $\mathbf{t}$ & $\boldsymbol{P}$ \\
\hline Intercept & -0.16 & 0.31 & 13 & -0.52 & 0.61 \\
& & & & & \\
Male investment in building & 0.51 & 0.39 & 13 & 1.30 & 0.21 \\
& & & & & \\
Treatment & -0.37 & 0.38 & 13 & -0.97 & 0.35 \\
\end{tabular}


625 Table S2. Influence of male investment in building and treatment on the proportion of time the 626 female spent in contact with the male of the left versus right side of the maze $(n=15)$. We used a 627 Generalized linear mixed model fitted by penalized quasi-likelihood (glmmPQL, binomial error), with 628 male pair's identity as a random effect. We included two explanatory variables: a binary variable 629 concerning male investment in building ( 1 if the male on the left was the one that invested the most in 630 building behaviors, 0 if it was the male that invested the least) and a binary variable reflecting the 631 treatment ( 1 if the female observed male building behaviors, 0 if not). The initial model also 632 considered the interaction between male investment in building and treatment, but it was excluded 633 during model simplification due to its non-significance.

634

635

\begin{tabular}{lccccc}
\hline Predictor variables & Estimate & S.E. & df & $\mathbf{t}$ & $\boldsymbol{P}$ \\
\hline Intercept & -1.16 & 0.59 & 8 & -1.96 & 0.09 \\
Male investment in building & 2.51 & 0.68 & 8 & 3.69 & 0.006 \\
& & & & & \\
Treatment & -0.16 & 0.70 & 8 & -0.23 & 0.83 \\
& & & & & \\
\hline
\end{tabular}


Figure S1: Photographs of mounds built in captivity 
At the beginning of the experiment, the soil of each terrarium was uniformly covered with earth and stones. Additional material (straw and seeds) were added weekly at the center of each terrarium.

All mice built a nest made of straw in a corner of the terrarium (A), and constructed a 'mound like' stucture made of stone and straw (B). Under some parts of the 'mound like' structures we observed the presence of seeds indicating seeds transport, gathering and storage (C). Tunnels were also observed (D).

A
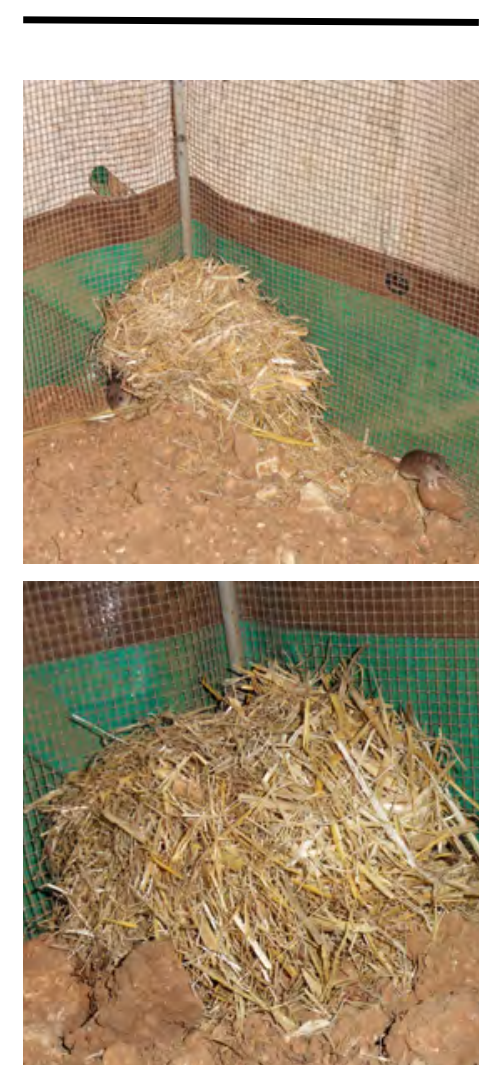

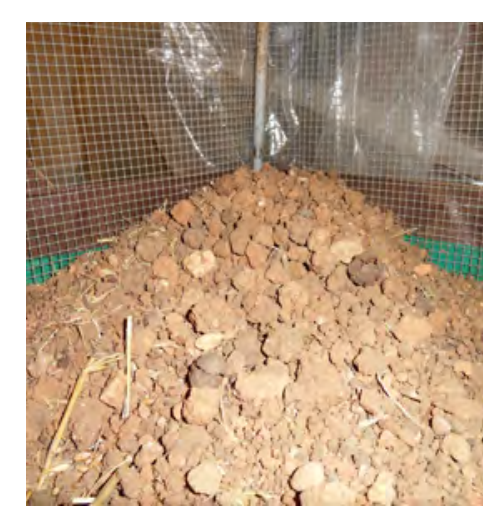

C
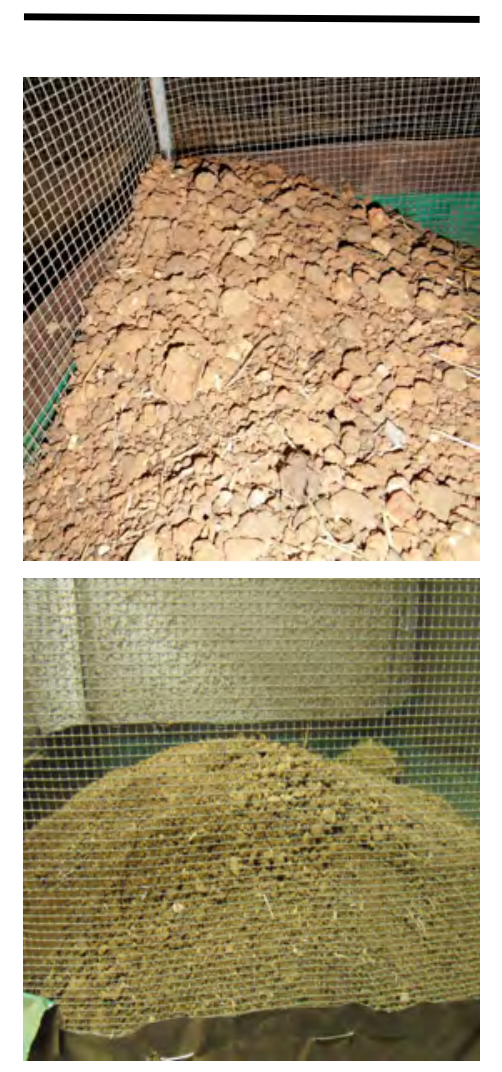
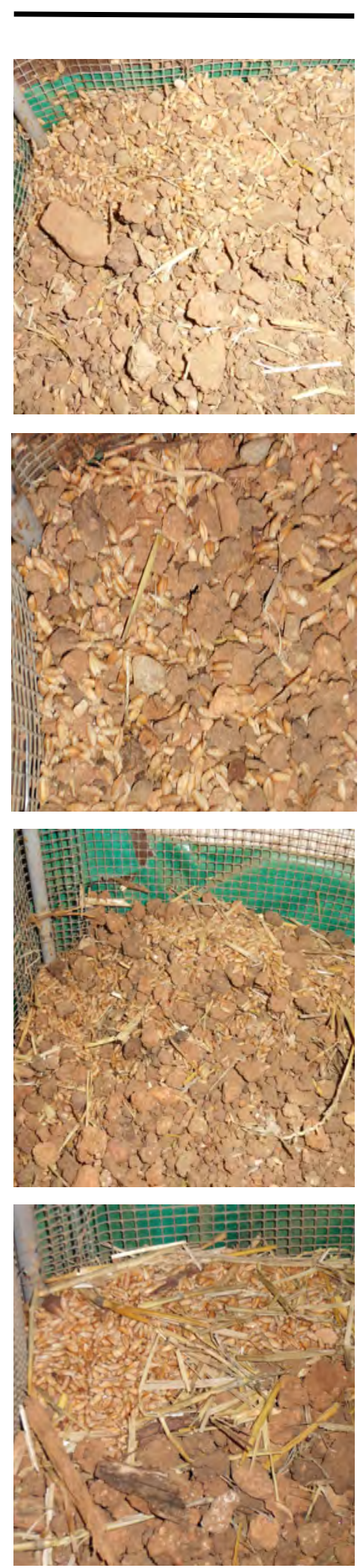

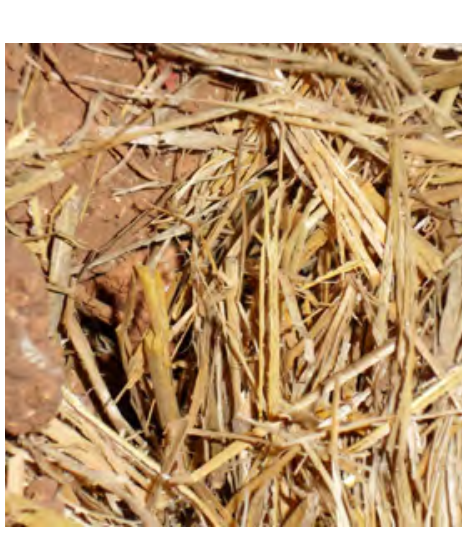

